\title{
ARTE/ARQUIVO: conexões possíveis entre Hubert Duprat, Alfredo Jaar e Rosângela Rennó
} ART / ARCHIVE: possible connections between Hubert
Duprat, Alfredo Jaar and Rosângela Rennó

Luciane Ruschel Nascimento Garcez ${ }^{1}$ Valeska Bernardo Rangel ${ }^{2}$ 


\section{Resumo}

Este artigo faz uma análise da obra do artista francês Hubert Duprat (1957-),"Trichoptère: la dernière bibliothèque", prefigurando uma biblioteca, onde o assunto abordado pela coleção são as larvas Tricópteras, e o material disponibilizado é composto, na sua grande maioria, pela coleção do artista. Problematizando questões como o arquivo que se torna obra de arte, Duprat propõe um trabalho onde memória e coleção são transpassados pela arte, e o espectador é convidado a interagir com o acervo e com seus conceitos, em uma movimentação onde Duprat reinventa sua própria coleção, sua forma de se apresentar ao público como artista, colocando em questão os conceitos de exposição, coleção e arquivo. Para estabelecermos um diálogo com esta obra, trazemos o artista chileno Alfredo Jaar (1956-), cuja poética igualmente permeia a noção de arte enquanto arquivo, bem como uma instalação de Rosângela Rennó (1962-) onde percebemos relações e conexões com os trabaIhos apresentados, nos quais percebemos a inserção do artista por um movimento de colecionismo, onde as obras têm sua corporalidade repensada e o artista nos faz refletir sobre o que são estas plataformas constitutivas da arte.

Palavras-chave: Arquivo; memória, Hubert Duprat; Alfredo Jaar; Rosângela Rennó.

\section{Abstract}

This paper analyzes the work of the French artist Hubert Duprat, "Trichoptère: la dernière bibliothèque", prefiguring a library, where the subject covered by the collection is the Tricoptera larvae, and the material available is mostly composed by the collection of the artist. Duprat proposes a work where memory and collection are pierced by art, and the spectator is invited to interact with the collection and its concepts, in a movement where Duprat reinvents his own collection, his way of presenting himself to the public as an artist, calling into question the concepts of exhibition, collection and archive. To establish a dialogue with this work, we bring the Chilean artist Alfredo Jaar, whose poetry also permeates the notion of art as archive, as well as an installation of Rosângela Rennó, where we perceive relationships and connections with the works presented, in which we perceive the insertion of the artist by a movement of collecting, where the works have their corporeality rethought and the artist makes us reflect on what are these platforms constitutive of the art.

\section{Keywords: Archive; memory; Hu- bert Duprat; Alfredo Jaar; Rosângela Rennó.}

ISSN: 2175-2346

${ }^{1}$ lucianegarcez@gmail.com

22valeskabr@gmail.com 


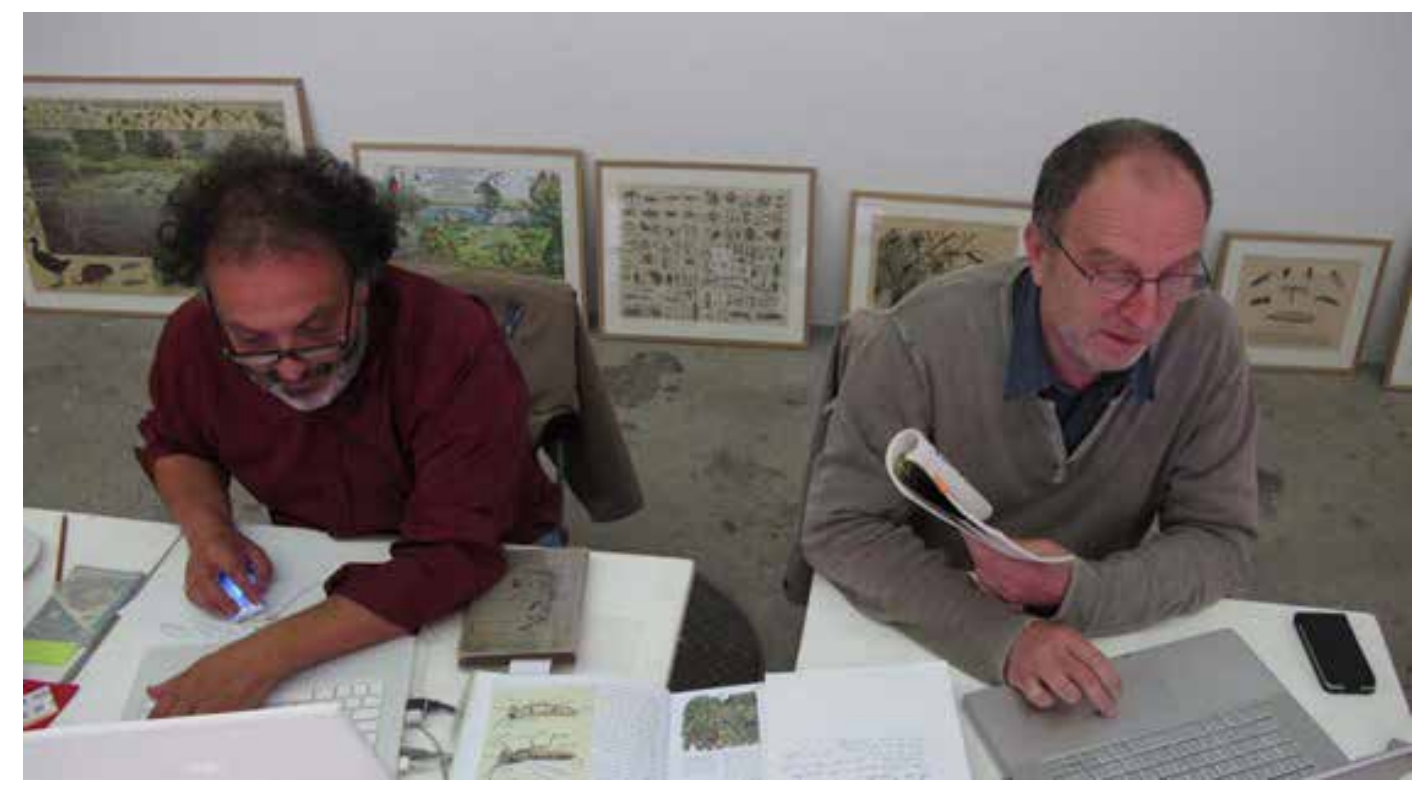

Fig. 1 - Vista da instalação com o artista Hubert Duprat à esquerda

Fonte da imagem: http://trichoptere.hubert-duprat.com/la-derniere-bibliotheque/exhibition-views/

\section{A respeito da biblioteca de larvas}

A partir de uma proposição para pensar a arte e suas fronteiras com relação às formas de criação, produção, apresentação e de divulgação, considerar os imateriais como a própria matéria prima, repensar o arquivo, a coleção e a memória, bem como refletir sobre os modos de exposição possíveis no contemporâneo, a corporalidade da obra e o papel das plataformas online no curso da arte, propomos uma reflexão a partir de um trabalho instigante do artista francês Hubert Duprat (1957-): "Trichoptère: la dernière bibliothèque", (Tricóptera: a última biblioteca). A obra parte de um trabalho anterior do mesmo artista, e a partir do qual Duprat se tornou reconhecido mundialmente no âmbito das artes, que são os casulos de ouro e pedras preciosas executados pelas larvas Tricópteras ${ }^{1}$ (1983 - 2015).

"Trichoptère: la dernière bibliothèque" foi apresentado em 2012, na galeria LivelnYourHead da Haute Ecole d'Art et de Design (Alta Escola de Artes e Design) de Genebra, na Suiça, de 12 de junho a 14 de julho. A obra é constituída de documentos - textos, livros, imagens, objetos, filmes - sobre as larvas da ordem das Tricópteras, documentos estes colecionados por Hubert Duprat ao longo de 30 anos de pesquisas, referindo-se ao início do período em que os casulos foram criados originalmente.

A obra/exposição foi executada como segue:

Ao fundo da sala, prateleiras metálicas de cinco metros de largura ocupadas por livros. Os mais raros e preciosos foram colocados em vitrines, entre eles a primeira monografia sobre as Tricópteras, publicada em 1834 por um entomologista suíço, François-Jules Pictet (1809-1872). Nas paredes uma coleção de imagens emoldu-

1 Veremos mais a este respeito mais adiante. 
radas: gravuras e desenhos agrupados em ordem cronológica. Uma seleção de imagens apresentava um resumo histórico da ilustração científica, a mais antiga datando do final do século XVI. Nas vitrines estavam também casulos vazios, fósseis da Sibéria e outros objetos relacionados às larvas, como por exemplo sapatos ornamentados com casulos vazios. Igualmente à disposição um documentário, Stone Dolls, feito por Minori Matsuoka, e escrito especialmente para o evento, onde Taiyou Yokota conta uma lenda japonesa a respeito deste inseto. $O$ documentário foi filmado no museu de Yamaguchi, que se encontra nas proximidades de um rio pleno destes insetos, em uma região onde várias lendas a este respeito são contadas.

Haviam também três vídeos sobre este mesmo assunto. Entre eles, um filmado por Hubert Duprat em 1998, "Éducation du Trichoptère" (Educação da Tricóptera), mostrando parte do processo de construção dos casulos de ouro nos aquários. Para completar esta coleção arquivista artística, haviam três grandes painéis na parede (BESSON, 2013, s/p).

A primeira parte da coleção era composta de uma seleção bem diversificada, com livros científicos e ficções; a segunda parte propunha um repertório de diversas denominações das Tricópteras em usos em várias línguas (entre as quais chinês, árabe, entre tantas outras). E a terceira parte desta coleção era intitulada "titres de l'exposition qui avaient échappé" (títulos da exposição que haviam escapado): aqui estavam colocados documentos, textos e livros que mostravam como o assunto das Tricópteras podia passar da série documental para a mitologia, atravessando temáticas como o lazer, a pesca, literatura infantil, e também criações plásticas. Esta seção mostrava que os insetos navegaram entre a erudição científica mais séria e restrita às incursões mais ficcionais (BESSON, 2013, s/p).

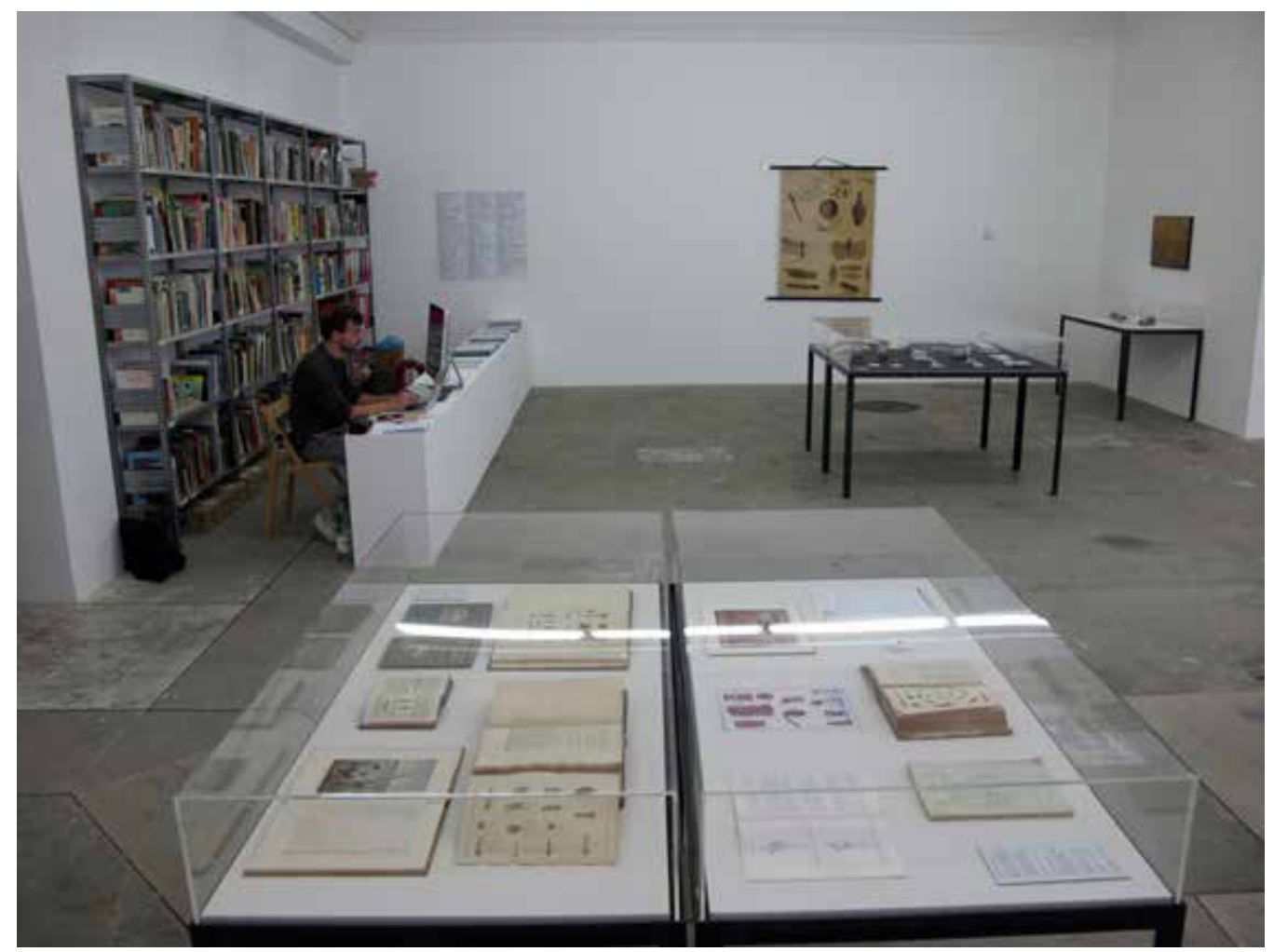

Fig. 2 - Trichoptère: La Dernière bibliothèque

Em primeiro plano, à esquerda, vitrines com gravuras dos séculos XVIII e XIX, à direita, a vitrine em pleno processo de experimentação. Fonte da imagem: http://trichoptere.hubert-duprat.com/la-derniere-bibliotheque/exhibition-views/ 
O resultado deste acervo de documentos coletados por Duprat ao longo dos anos, e desta exposição, foi um site na Internet, Miroir du Trichoptère / The Caddisfly's Mirror $^{2}$, criado pelo artista, onde ele disponibiliza mais de mil arquivos sobre as larvas Tricópteras, textos, imagens e outras informações diversas sobre este inseto que vem fazendo parte de sua vida desde o início dos anos 80, assim como artigos publicados sobre seu trabalho artístico com os insetos: seus casulos de ouro.

$\mathrm{Na}$ noite do vernissage, caixas de acrílico transparente, cheias de reproduções de imagens e documentos, foram colocadas no centro de uma grande mesa no meio da sala de exposições. Os visitantes inscritos foram convidados a se sentar e desfrutar de um jantar/debate oferecido por Bertrand Prévost, o filósofo convidado a discutir o assunto, junto com o artista, Hubert Duprat. As caixas foram abertas e os documentos distribuídos para apreciação de todos. Segundo Christian Besson, esta seria uma outra maneira de desfrutar a exposição (2013, s/p). Ao longo do vernissage, os visitantes sentados ao redor da mesa, jantando, bebendo vinho, e discutindo assuntos ligados aos insetos e seus desdobramentos. Esta foi uma forma bem diferente do tradicional vernissage, com coquetel de abertura. Foi igualmente lançado um fórum de discussão que vai além da palavra do artista. Neste caso, as pessoas se encontraram cara a cara com as questões colocadas por Duprat, um debate muito mais próximo da interação espectador/obra/proposição artística usual. O artista assim reinventa sua própria coleção, mas também reinventa seu conceito sobre arte e seus modos de exposição, nos fazendo inclusive questionar, foi mesmo uma exposição?

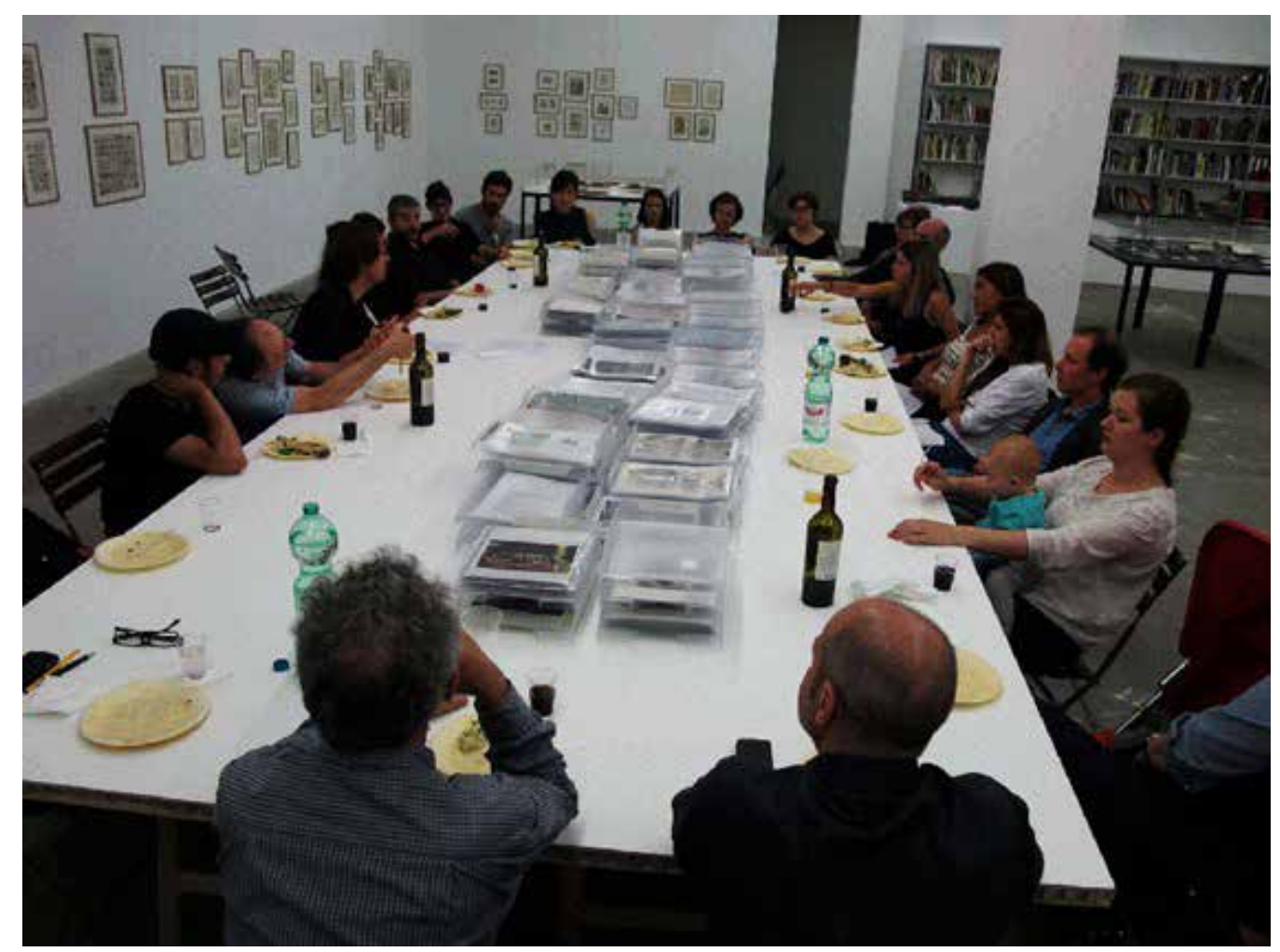

Fig. 3 - Trichoptère : La Dernière bibliothèque - jantar/debate com Hubert Duprat Fonte da imagem: http://trichoptere.hubert-duprat.com/la-derniere-bibliotheque/exhibition-views/

2 http://trichoptere.hubert-duprat.com/ 
Nesta proposta artística, vemos um alargamento de fronteiras da arte. Como comentado por Christian Besson:

Nem obra de arte, nem pesquisa científica, nem mesmo arquivo de artista, a Biblioteca das Tricópteras configura um objeto não identificado, largamente inclassificável. Notemos de passagem que a erudição de Hubert Duprat não é um trompe l'œil, como em Borges: sua biblioteca não é imaginária, ele não se vale de um método científico ${ }^{3}$. Se, como escreveu em algum lugar Gérard Genette, "a forma moderna do fantástico, é a erudição", é preciso acrescentar que em nosso artista, sua ficção é verdadeira de parte a parte. (BESSON, 2013, s/p) .

\section{Um pouco do início: sobre os casulos de ouro}

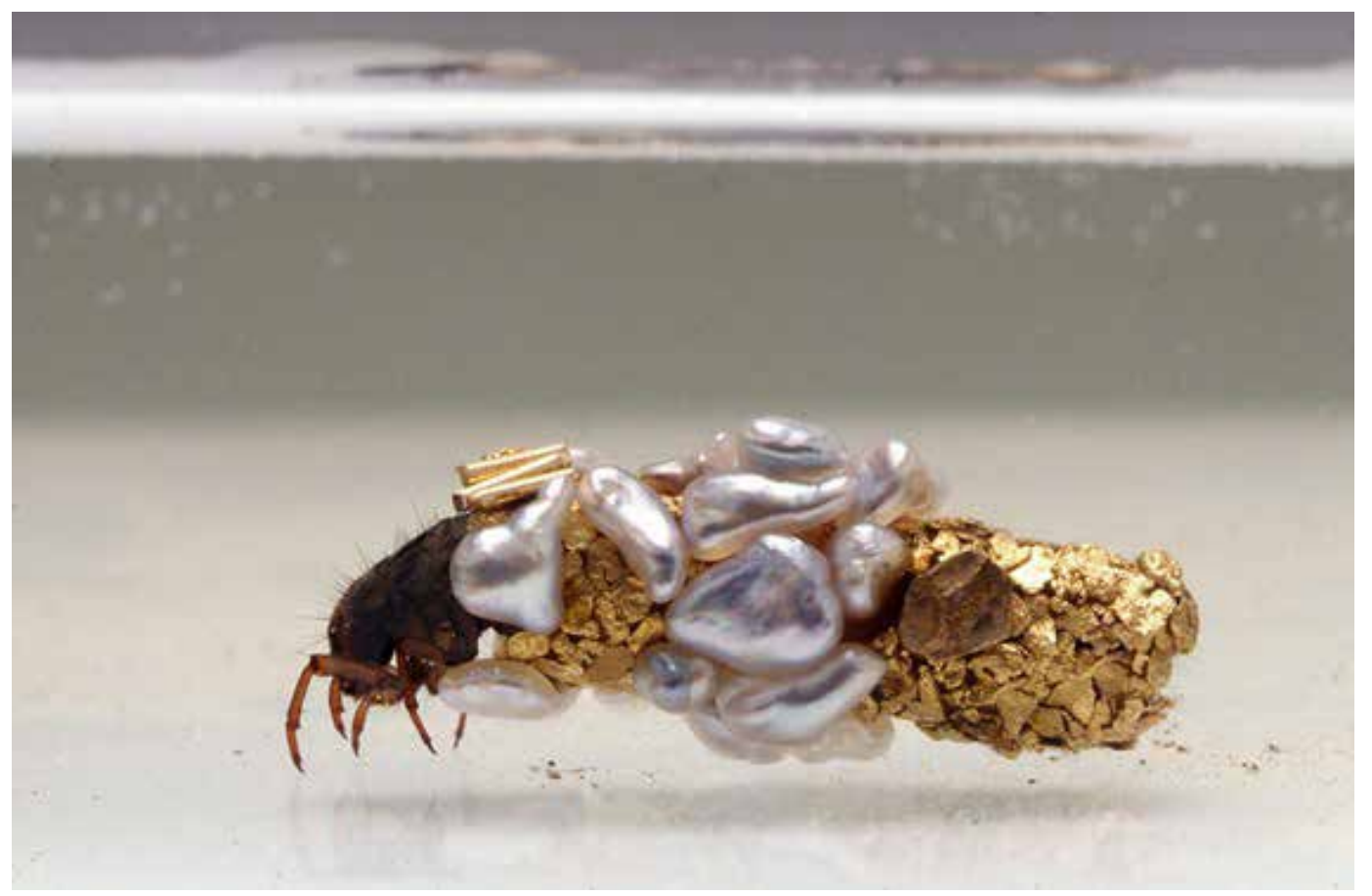

Fig. 4 - Hubert Duprat - Casulo de ouro e larva (1980 - 2015) Fonte da imagem: imagem fornecida pelo artista.

Tudo começou com os casulos. A pesquisa do artista sobre estas larvas começou como uma curiosidade científica ${ }^{5}$, e se tornou arte, agora virou arquivo e plataforma online, ficcional, científica, artística, documental. As larvas Tricópteras, insetos existentes no mundo há milhões de anos, são reconhecidas por construírem seus casulos de proteção a partir de qualquer que seja o material disponível nos rios onde estas se encontram. Existem casulos ancestrais destas larvas, em diversas culturas, ao redor do mundo, feitos com pedras, galhos, conchas, folhas, grãos de cereais, etc.

\footnotetext{
3 Duprat não selecionou um método científico para organizar sua coleção de textos e imagens a respeito destes insetos, toda informação é válida (nota das autoras).

4 Ni œuvre d'art, ni recherche scientifique, ni même archive d'artiste, la Bibliothèque du Trichoptère demeure un objet non identifié, largement inclassable. On notera au passage que l'érudition de Hubert Duprat n'est pas en trompe l'œil, comme chez Borges : sa bibliothèque n'est pas imaginaire, il ne mime pas une méthode scientifique. Si, comme l'a écrit quelque part Gérard Genette, "la forme moderne du fantastique, c'est l'érudition », il faut ajouter que chez notre artiste, sa fiction est vraie de part en part (tradução das autoras).

5 Esta foi uma informação dada pelo próprio artista ao autor em conversas a respeito de sua trajetória artística.
} 
A experiência artística de Hubert Duprat começa pela coleta das pequenas placas e lingotes de ouro, que constituem matéria-prima para a confecção dos casulos. Em um segundo momento vêm as pérolas e outras pedras preciosas, como turquesa, coral, entre tantas outras. O artista prepara os aquários onde este material será colocado. Em seguida o artista coleta os insetos e os deposita nestes aquários, onde a água é tratada e mantém uma temperatura de cerca de $5^{\circ} \mathrm{C}$. No primeiro aquário as larvas constroem o que será o primeiro casulo - um tubo protetor simples, somente de ouro. Esta etapa dura de dois a três dias. Os tubos devem ser suficientemente resistentes para serem manipulados sem risco de quebrarem. Para cada material que o artista deseja que seja utilizado pelas larvas, ele as transfere a reservatórios separados, cada qual com seu material específico, ou seja, as diferentes pedras preciosas. A construção total do casulo dura alguns meses, e é um movimento dinâmico, entre artista e larva, onde o inseto algumas vezes refaz seu tubo, o abandona, adota outro.

Duprat conduz habilmente a composição dos casulos, controlando a duração de tempo das larvas em cada reservatório, e por vezes pela supressão de certas partes do casulo, o que obriga a larva a fazer um reparo neste. O resultado desta operação são pequenas esculturas, que o artista vem expondo desde os anos 80 .

Em 1983 Duprat registrou a patente internacional deste processo de confecção de casulos com ouro e pedras preciosas pelas larvas. Desde então estes pequenos insetos têm incentivado o artista a aprender cada vez mais sobre suas histórias, costumes, hábitos, mitos e lendas. Duprat vem colecionando livros, textos, documentos, gravuras, desenhos, vídeos sobre as Tricópteras, provenientes do mundo todo. Não somente este trabalho o lançou no mundo da arte contemporânea, como o processo de fatura destes casulos desencadearam um movimento de colecionador, arquivista, próprio de Hubert Duprat, culminando na obra supracitada, "Trichoptère: La Dernière bibliothèque", obra de arte para seu criador, arquivo no site de Internet resultante.

Ao longo de suas pesquisas com as Tricópteras, o artista se deu conta de que não estava sozinho em seu interesse pelo assunto. Christian Besson comenta o fato no texto que escreveu para a exposição:

Ele rapidamente descobriu, não sem surpresa, que outros antes dele - Miss Smee, por exemplo, já em 1863 - tinham realizado experiências in vitro. Ele poderia ter permitido que esta camuflagem continuasse a esconder o primado do que ele acreditava ser sua invenção; ele não fez nada disso; ele desenvolveu uma pesquisa inteira $(2013, \mathrm{~s} / \mathrm{p})^{6}$.

No início deste processo de coletar informações, Duprat começou copiando extratos de textos, páginas, reproduções de imagens das larvas, ao longo do tempo ele começou a procurar em livrarias, bibliotecas, em qualquer lugar, qualquer informação que pudesse acrescentar à sua coleção, sua biblioteca de Tricópteras. Durante o percurso, com o aumento de sua coleção, o artista entrou em contato com outros pesquisadores, cientistas, tanto da sua região como em outros locais. Em suas via-

6 Ce faisant il a rapidement découvert, non sans surprise, que d'autres avant lui - Miss Smee, par exemple, dès 1863 - avaient réalisé des expériences in vitro. II aurait pu laisser cacher ce camouflet à la primauté de ce qu'il croyait être son invention ; il n'en a rien fait ; il a développé toute une enquête (tradução das autoras). 
gens ele encontrou materiais preciosos para suas pesquisas, como Moretti em Pérouse, e Isao Yokota em Iwakuni, no Japão (BESSON, 2013), pelo caráter mitológico desenvolvido nos referidos textos.

\section{Memória e arquivo}

O artista trabalha com a memória cultural, artística e científica, mas trabalha também com sua memória pessoal, alguma coisa de muito íntimo e privado que ele transmite ao público de maneira catalogada e disponível. Assim nasceu o que Christian Besson, teórico e amigo pessoal de Hubert Duprat, chamou de "trichopterotheque", misturando as Tricópteras com a biblioteca, uma ação obstinada e compulsiva, que ele nos apresenta pela primeira vez em Genebra.

É mais o trabalho de uma pessoa curiosa, especialmente interessada na larva e sua capacidade de fazer um casulo. Esta curiosidade não abrange somente estudos entomológicos, mas testemunha, por exemplo, o interesse que os pescadores têm por esta larva; a literatura destinada aos jovens também não falta, que muitas vezes cita o animal; podemos também citar as passagens que podem ser encontradas em romances ou poemas; a própria ficção também a comporta (BESSON, $2013, \mathrm{~s} / \mathrm{p})^{7}$.

A coleção foi organizada a fim de que o visitante tivesse acesso às obras numeradas, como em uma biblioteca tradicional. Os funcionários do espaço expositivo exerceram a função de bibliotecários, sentados atrás das mesas oferecendo informações, volumes, e ajudando na escolha das obras a serem pesquisadas pelos espectadores. O público foi convidado a fazer relações imagéticas e conceituais nos painéis disponíveis, onde no centro destes haviam já algumas imagens, fotografias, a partir das quais as relações deveriam ser tecidas. As pessoas foram convidadas a dar suas próprias interpretações a respeito de assuntos que versassem acerca das larvas Tricópteras, complementando as metáforas, os mitos já disponíveis no arquivo.

Não podemos deixar de citar Aby Warburg e sua Mnémosyne, onde a pulsão pelo arquivo foi referência na criação do Atlas, que vem inspirando a teoria da arte recentemente. Vemos nesta obra, "La dernière bibliothèque", uma referência direta ao Atlas de Warburg, que é um dos autores muito apreciados por Hubert Duprat, e o artista não se furta a nos dar suas referências, ele abre suas discussões a partir de seus referenciais. O espectador podia desenvolver seu próprio painel, uma constelação de imagens pessoais, como no exemplo do historiador alemão e seus painéis.

No que se refere a esta proposição artística de Duprat, de convidar o público a uma interação com seu trabalho, um movimento que não vimos ainda em seu corpus poético, trazemos uma citação de Besson (2013, s/p):

Eles poderiam constituir nuvens interpretativas a partir de certas imagens coladas ao centro de grandes painéis, adicionando em torno suas próprias imagens. [...] A ficção da Última Biblioteca, sua suposta sobrevivência, foi assim realizada pelos próprios visitantes. E o resultado, localizado, lembremos, na galeria de exposi-

7 C'est plutôt l'œuvre d'un curieux, tout spécialement intéressé par la larve et sa capacité à fabriquer un fourreau. Elle ne comporte donc pas seulement des études entomologiques, mais témoigne, par exemple, de l'intérêt que les pécheurs au lancer portent à la larve ; la littérature destinée à la jeunesse ne manque pas non plus, qui cite souvent l'animal ; on peut relever également des passages chez des romanciers ou des poètes ; la fiction, même, s'en est emparée (tradução das autoras). 
ções de uma escola de arte, não poderia não evocar, aos visitantes, professores e estudantes, os painéis do Atlas Mnémosyne de Aby Warburg8 8

É inegável a relação entre o movimento de Duprat e o de Warburg, sua maneira de reinventar os painéis a partir de sua própria coleção, tendo como linha condutora o inseto que tanto encanta o artista. Duprat não se reduz a uma classificação de textos, ele faz uso de documentos científicos, livros infantis, artefatos antropológicos, literatura ficcional. Faz uma relação à cultura, não somente à arte, como sabemos igualmente de Warburg. Duprat traz desta forma a imagem/informação independentemente de sua classificação, imagens por similaridades, constelações de relações, deixando estas conexões livres de serem repensadas e estendidas por visitantes das mais diversas procedências e referenciais.

A Última Biblioteca constitui de fato uma espécie de telescópio temporal entre o passado pré-histórico - os traços mais antigos dos casulos de Tricópteras são fósseis jurássicos que remontam a cerca de 150 milhões de anos - e o futuro da ficção científica. Lembremos que a arqueologia foi uma das primeiras paixões de Hubert Duprat, que em sua juventude publicou um estudo sobre Cerâmica Galo-Romana (BESSON, 2013, s / p) .

Nesta citação percebemos a variedade de interesses de nosso artista, da entomologia à arqueologia. Não seria esta uma experiência intelectual que poderia ser vivida dentro de uma biblioteca? A possibilidade de desfrutar de diversos campos de conhecimento em torno do mesmo sujeito? Onde estão as fronteiras? Não seria este o papel do artista, colocar em questão nossas certezas? Repensar modos de expor e eternizar suas obras?

E é neste momento que Duprat de certo modo subverte o papel da biblioteca, pois ele oferece o que normalmente fica guardado. No uso comum de bibliotecas não temos acesso direto aos documentos mais raros, antigos, como a publicação do século XVI que ele oferta generosamente ao seu público, normalmente estes não estariam disponíveis. $O$ artista quebra este paradigma, ele nos oferece tudo...

Anna Maria Guasch comenta acerca do "caráter aberto" de certos arquivos, e nos diz que podemos remeter à "natureza digital" da biblioteca de Duprat: "O que demonstra a natureza aberta do arquivo desde a apresentação das histórias é o fato de que seus documentos estão necessariamente abertos à possibilidade de uma nova opção para selecioná-los e recombiná-los, para criar uma narrativa diferente, um novo corpus e um novo significado no coração do arquivo" $\left(2013\right.$, p.239) ${ }^{10}$.

\footnotetext{
8 Ils pouvaient constituer des nuages interprétatifs à partir de certaines images collées au centre de grands panneaux, en ajoutant autour leurs propres images. [...] La fiction de la Dernière Bibliothèque, sa survivance supposée, était ainsi performée par les visiteurs eux-mêmes. Et le résultat, situé, rappelons-le, dans la galerie d'exposition d'une école d'art, ne pouvait pas ne pas évoquer, aux visiteurs, professeurs et étudiants, les panneaux de l'Atlas Mnémosyne d'Aby Warburg (tradução das autoras).

9 La Dernière Bibliothèque constitue en effet une sorte de télescopage temporel entre le passé préhistorique - les plus anciennes traces de tubes de Trichoptère sont des fossiles du Jurassique remontant à environ 150 millions d'années - et le futur de la science-fiction. Rappelons que l'archéologie fut une des premières passions de Hubert Duprat qui, dans sa jeunesse, publia même une étude sur la poterie sigillée gallo-romaine (tradução das autoras).

10 Ce que démontre la nature ouverte de l'archive lors de la présentation des histoires est le fait que ses documents sont nécessairement ouverts à la possibilité d'une nouvelle option pour les sélectionner et les recombiner, à fin de créer une narrative différente, un nouveau corpus et un nouveau sens au sein de l'archive (tradução das autoras).
} 
Como uma informação sem hierarquia, um buffet livre de livros, de textos, imagens, onde o espectador tem a oportunidade de se servir à vontade, o que talvez não seria possível em uma biblioteca tradicional, dado à raridade de certos materiais. Duprat questiona o conceito de biblioteca ao fornecer sem maiores restrições o que seria limitado à manipulação.

O movimento desenvolvido pelo artista nos convida a refletir sobre as fronteiras entre os conceitos de arquivo, de memória e de arte. Onde estão os limites que definem o quê é o quê? Qual o instinto que faz com que o artista não cesse jamais de pesquisar documentos sobre estes insetos, que estão longe do mundo da arte, mas tão próximos de seu corpus poético? Seria possível classificar esta reunião em Genebra de obra de arte? Ou o movimento empreendido pelo artista foi o de introduzir mais um espaço de pesquisa/coleção/reflexão sobre as Tricópteras, insetos que pertencem ao mundo da entomologia, da biologia? E como organizar os mitos e lendas que foram incorporados neste arquivo, e que trazem tanto fábulas quanto histórias a respeito destes insetos construtores? Estas são questões que transbordam o mundo da arte, e transbordam igualmente os meios científicos.

O artista nomeou seu trabalho de "a última biblioteca", o que parte da noção de arquivo, pesquisa, lugar de conhecimento e catalogação. Duprat problematiza estes conceitos ao chamá-la de "a última". "A última" como a última maneira de utilizar a biblioteca - como obra de arte -, ou como "sua" última proposição a respeito de seu arquivo documental, sua "tricopterateca"?

Vemos este movimento de biblioteca e arte também na história da arte, em outros momentos, onde pintores incluíram suas coleções, seus livros, seus manuscritos, fontes de conhecimento, nas composições de suas pinturas, imagens de permanência de seus arquivos e coleções representados em imagens da história da arte, numa tentativa de eternizar o que lhes era importante, e os definia de certa maneira. Não seria esta uma forma de tentar arquivar seus conhecimentos, deixando-os para a posteridade? Não seria este um movimento inerente ao homem: tentar guardar, coletar o que lhe é caro e precioso?

\section{A respeito das fronteiras entre arte e arquivo}

Refletir a respeito da arte e suas fronteiras, onde buscamos o uso do arquivo como poética, nos ajuda a compreender, a ler, algumas obras propostas por artistas que discutem estes conceitos, assim como Hubert Duprat.

Anna Maria Guasch, crítica de arte e professora de história da arte, refletiu a respeito do arquivo no mundo das artes. Escreveu acerca de práticas arquivistas contemporâneas, trazendo o arquivo na arte, um movimento que se encontra entre o público e o privado, entre memória e história. Características que podemos encontrar na proposição de Duprat em sua "última biblioteca". A respeito deste posicionamento entre global e local, menciona Guasch (2013, p. 238):

Referindo-se à arquitetura do arquivo (ou ao complexo físico da informação) e à lógica do arquivo enquanto matriz conceitual de citações e justaposições, os materiais da obra de arte enquanto arquivo podem ser encontrados (imagens, objetos e textos) ou construídos antes, tanto públicos quanto privados, ao mesmo tempo 
reais, fictícios ou virtuais. Neste último caso, o espaço próprio da arte do arquivo seria a Internet, o que confunde e substitui os limites entre o privado e o público. ${ }^{11}$

E encontramos Duprat exatamente neste movimento que Guasch aborda, seu espaço da obra inicia em Genebra, mas aterrissa na Internet através do site, já mencionado. $O$ artista expande sua coleção, mas percebemos nesta intenção, a vontade de permanência, além do transbordar dos limites da arte. Encontramos no arquivo de Hubert Duprat diversas informações acerca de incontáveis áreas sobre as larvas Tricópteras. Não temos aqui uma linha de conhecimento que permeie seu trabalho [os casulos de ouro já mencionados], mas sim a larva. Em outras palavras, temos também sua obra de arte mais famosa. Seria esta uma maneira de questionar a própria arte?

A maior parte dos artistas que conhecemos trabalham a arte enquanto arquivo, como arquivo: Alfredo Jaar, Rosângela Rennó, Christian Boltanski, Gerhard Richter, entre outros. Duprat faz o movimento inverso: ele transforma seu arquivo em obra. Desconstrói esta poética, transforma seu instinto de colecionador na própria obra.

Sabemos que o arquivo não será jamais a memória, em sua experiência viva e interior. $\mathrm{O}$ arquivo é o fantasma, o resíduo. Segundo Jacques Derrida, "o arquivo se localiza em (o) lugar de desvanecimento originário e estrutural desta memória"12 (1997, p.19). Neste lugar não encontramos a experiência em si mesma, nem estética, nem científica, o que temos é a estrutura, o referencial, que deu lugar a ela, ou o resíduo desta estrutura. $E$, portanto, o artista continua sem descanso a se dedicar a esta coleta de documentos, e a tentar remediar o que o escapa. Não seria este o "mal de arquivo" ao qual se refere Derrida? Esta obsessão de tudo conhecer, tudo saber, e de coletar todo conhecimento? "La dernière bibliothèque" funciona como uma coleção/reposição de memórias. E culmina no site, pois somente a exposição não dá conta de suprir este desejo de arquivo. "Porque o arquivo não está limitado à memória: ocorre no colapso da memória. Não há arquivo sem uma remessa em um local estrangeiro que garanta a possibilidade de repetição, reprodução ou reimpressão. Além disso, o arquivo implica - acima de tudo - a criação de um corpo ou um lugar de autoridade "13 (KLINGER, 2008, s/p).

Arquivo e memória parecem ser conceitos muito importantes no contemporâneo. O desejo que mostramos de tudo saber e tudo guardar é um movimento que atravessa as gerações, as camadas sociais e culturais. Temos medo de perder as memórias, lembranças, informações. Hubert Duprat criou uma forma de organizar sua coleção e de torná-la disponível. Para Derrida, o arquivo ao mesmo tempo que guarda, também revela, elucida, neste sentido ele é um cofre de memórias que esconde, e é uma fonte que oferece e mostra as provas. Duprat nos oferece um duplo movimento do arquivista: o físico, do colecionador ancestral, e o virtual, do arquivista

11 En se rapportant à l'architecture de l'archive (ou le complexe physique de l'information) ansi qu'à la logique de l'archive tandis que matrice conceptuelle des citations et des juxtapositions, les matériaux de l'œuvre d'art en tant qu'archive peuvent être trouvés (images, objets et textes) ou construits avant, à la fois publics et privés, en même temps réels, fictives ou virtuels. Dans ce dernier cas, l'espace propre de l'art de l'archive serait l'Internet, qui confond et remplace les frontières entre le privé et le public (tradução das autoras).

12 L'archive à l'endroit dans (le) lieu d'évanouissement originaire et structurel de cette mémoire (tradução das autoras).

13 Parce que l'archive ne se limite pas à la mémoire : elle a lieu dans l'effondrement de la mémoire. II n'y a pas d'archive sans consignation dans un lieu étranger qui garantit la possibilité de la répétition, de la reproduction ou de la réimpression. En outre, l'archive implique - surtout - à la création d'une instance ou d'une place d'autorité (tradução das autoras). 
contemporâneo. "Não existe nenhum arquivo [...] sem uma certa exterioridade; não existe nenhum arquivo sem exterior"14 (DERRIDA, 2001, p. 22). Não vivemos mais da mesma forma que antigamente, não arquivamos mais das mesmas maneiras. $O$ arquivo continua vivo, é transformado, ressignificado, em função daquilo que gera.

\section{Sobre os usos dos arquivos na arte contemporânea: uma ponte com a bi- blioteca de larvas.}

O uso dos acervos de livros, das diferentes formas de arquivos é recorrente na obra de vários artistas contemporâneos. Apaixonados pelo objeto livro além do próprio conhecimento que podem oferecer, alguns artistas começam colecionando um ou outro volume e ao final nos deparamos com coleções de verdadeiros especialistas em determinados temas. Como um dos possíveis interlocutores de Hubert Duprat, apresentamos o artista chileno Alfredo Jaar (1956-), uma vez que sua poética dialoga em várias obras com o movimento arquivista e a subversão/dessacralização da biblioteca para além de mero espaço de pesquisa e disseminação de conhecimento, além da reinvenção do artista em suas formas de produzir arte e de mostrá-la ao público. Jaar transforma em banquete, espaço de celebração, espaço de encontros.

Neste sentido, percebemos muitas conexões entre "A Biblioteca de Larvas" de Hubert Duprat e as obras "The Marx Lounge" (2010), e "El lamento de las imágenes" (2002) de Alfredo Jaar. Em Duprat o trabalho continua vivo, se dilata, se desdobra. O artista trouxe diversos livros, inúmeras referências a partir de vários arquivos e bibliotecas e os reorganizou em seu próprio espaço/trabalho/biblioteca, organizando este fluxo onde circulam as informações a respeito destes insetos, que de outro modo estariam dispersos pelo mundo. Entusiasta e colecionador, conservador e pesquisador do conhecimento científico que se torna artístico em suas obras.

Nos parece que os usos e apropriações dos arquivos na arte contemporânea estão ligados ao excesso de informações e de imagens que temos em circulação. Também o protagonismo do arquivo teria outras justificativas que atravessam as políticas da memória em nossa cultura contemporânea: a ancoragem referencial de imagens entendidas como documento e a (re)conceitualização do arquivo como um discurso baseado nas teorias de Foucault ${ }^{15}$ (MONEGAL, 2011).

Alfredo Jaar vem desde muitos anos trabalhando em diferentes projetos para dar conta da questão dos processos de produção e circulação das imagens. Para tanto ele faz uso frequentemente de duas operações específicas: a não-produção de imagens e a não exibição das imagens produzidas. Além das (não) imagens, Jaar usa a palavra como elemento essencial no processo de construção do discurso através do arquivo (MONEGAL, 2011).

14 II n’y a aucun archive [...] sans une certaine extériorité ; il n'y a pas d'archive sans extérieur (tradução das autoras).

15 El anclaje referencial de las imágenes entendidas como documento y la reconceptualización del archivo como discurso a partir de las teorías de Foucault (tradução das autoras). 


\section{The Marx Lounge (2010)}

Além de centenas de livros de e sobre Marx, você encontrará teóricos políticos e filósofos como Žižek, Hall, Rancière, Butler, Laclau, Mouffe, Jameson, Bourdieu, Fanon, etc. Para mim, esses escritos nos oferecem modelos de pensar o mundo. E é isso que eu tento fazer como artista - eu crio modelos de pensamento. Eu vejo o Marx Lounge como um espaço de resistência, ou como David Harvey o chamaria, um espaço de esperança ${ }^{16}$ (Alfredo Jaar, Art Monthly, janeiro de 2011).

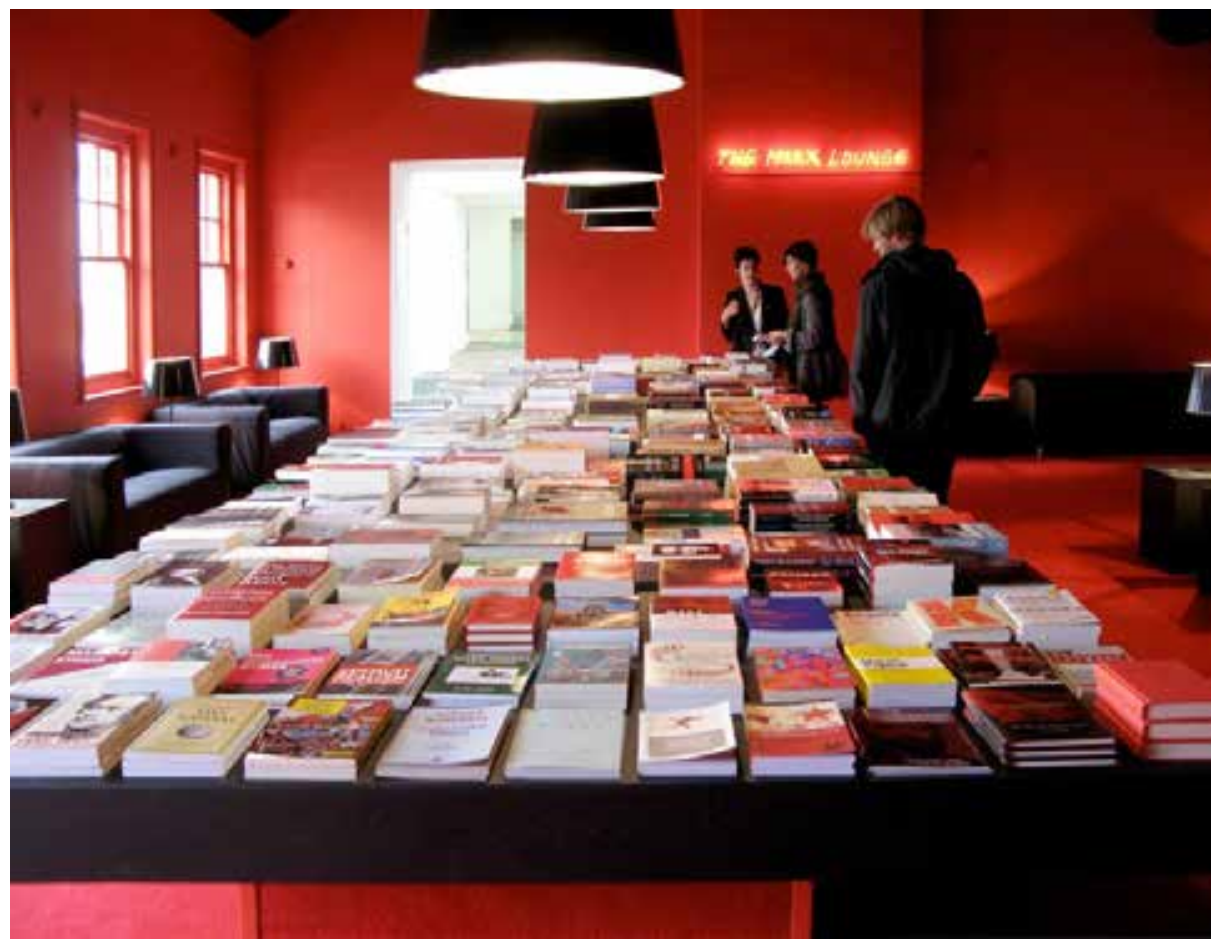

Fig. 5 - Alfredo Jaar: The Marx Lounge, Liverpool Biennial, UK, 2010.

Fonte da imagem: http://whitney.org/image_columns/0036/8117/jaar_themarxlounge_2010_web_800

Este trabalho de Alfredo Jaar se inscreve em sua larga trajetória, onde o artista sempre procurou que o espectador saísse transformado depois de visitar suas instalações, lhes solicitando uma mudança mental e física. Jaar reconhece que esse objetivo "não se alcança sempre, não se alcança quase nunca. Mas é este, no fundo, o que se trata aqui de fazer"17.

Seguramente estas mudanças são muito difíceis nos tempos atuais, onde a manutenção de sistemas seculares é bem-vinda e as mudanças são vistas com descaso. O artista aposta mais uma vez nessa obra que foi apresentada no Stedelijk Museum em Amsterdam (Holanda), como uma possibilidade a mais de produzir mudanças, ou ao menos provocar ruídos em nossas percepções. A instalação foi constituída por um espaço/sala/lounge que dispunha de confortáveis sofás, luminárias especiais para leitura e uma enorme mesa, onde estava à disposição do público uma grande quantidade de publicações relacionadas com o pensamento de Karl Marx (1818-1833), e dos

\footnotetext{
16 Besides hundreds of books by and about Marx, you will find political theorists and philosophers like Žižek, Hall, Rancière, Butler, Laclau, Mouffe, Jameson, Bourdieu, Fanon etc. For me these writings offer us models of thinking the world. And that is what I try do as an artist - I create models of thinking. I view The Marx Lounge as a space of resistance, or as David Harvey would call it, a space of hope (tradução das autoras).
}

17 No se logra siempre, no se logra casi nunca. Pero este es en el fondo, es lo que se trata aquí de hace. Alfredo Jaar, em entrevista a Cristián Warnken (2006). (tradução das autoras) 
diferentes autores que falam a partir dele, desde distintos campos como o capitalismo, neoliberalismo, pós-colonialismo, globalização, teoria cultural, política e filosofia. A obra se apresentava como um convite para que o espectador pudesse sentar-se e desfrutar destes documentos selecionados pelo próprio artista ${ }^{18}$. As paredes e o piso da sala/lounge eram todos em vermelho, em referência à ideologia apresentada. Outros autores que dialogam com a teoria marxista também foram oferecidos neste banquete: Slavoj Žižek, Stuart Hall, Jacques Rancière, Judith Butler, Ernesto Laclau, Chantal Mouffe, Fredric Jameson, Pierre Bourdieu, Frantz Fanon, entre outros.

Nos chama a atenção que vivemos assolados por um excesso de dados de todos os tipos, onde muitos têm acesso a variado tipo de informação, em especial a partir da explosão da internet. É curioso pensar que artistas como Jaar e Duprat se detenham em colocar a atenção ao objeto livro. Como uma espécie de bibliotecários-curadores, que selecionam e oferecem diferentes referências para alimentar o pensamento. Cobram um exercício de pausa e de atenção. A concretude do objeto físico "livro" parece devolver o "peso" necessário ao conhecimento disperso no universo virtual. Voltar-se aos livros, (re)organizar bibliotecas, chamar a atenção do público para eles e para os tempos da leitura. Claro que ninguém esperava ler os quase 350 livros oferecidos por Jaar durante o período da exposição. A reunião de todos eles no mesmo espaço, dispostos e oferecidos em uma mesma mesa, como um banquete, são também tributo e monumento à teoria que queria compartilhar. Assim como em outras de suas instalações, Alfredo Jaar nos interpela como um alerta: atenção! Está tudo aí, as ferramentas à vossa disposição, peguem os livros, leiam, estejam aptos a produzir encontros, a gerar diálogos e conexões possíveis!

Em The Marx Lounge encontramos também, dentro do inventário de Alfredo Jaar e de seus procedimentos críticos, os "protocolos de leitura, de observação e de análise como mecanismos principais de comprometimento" (ENWENZOR, 2012, p. $18)^{19}$. Neste sentido, o artista pensa esta obra a partir de um convite para que o público possa sentar-se para ler e refletir sobre a importância e viabilidade do marxismo no contexto contemporâneo e sobre as ideias políticas e filosóficas mais importantes surgidas nos últimos tempos. Ideias que podem servir-nos para compreender um pouco melhor nosso presente. ${ }^{20}$

\section{El lamento de las imágenes, 2002}

Consideramos "El lamento de las imágenes" uma obra bastante emblemática e oportuna para pensar o trabalho de Alfredo Jaar a partir do conceito de arquivo. Apresentada na Documenta 11 (Kassel, 2002), foi composta por três pequenos painéis em acrílico $(58,4 \times 50,8 \mathrm{~cm})$, que apresentavam em letras brancas luminosas três textos de autoria de David Levi Strauss ${ }^{21}$ (figuras 6, 7 e 8). A outra parte desta obra encontrava-se

\footnotetext{
18 http://www.smba.nl/static/en/exhibitions/the-marx-lounge/smba-newsletter-121.pdf

19 [...] Jaar pesents us wich asn inventory of his critical proceduresin wich protocols of reading, viewing, and analysis are the principal mechanisms of engagement (tradução das autoras).

20 http://www.caac.es/prensa/dossiers/dos_jaar11.pdf

21 Levi Strauss colaborou com Alfredo Jaar na instalação para a Documenta 11.
} 
em uma sala paralela e consistia em um painel iluminado $(182,9 \times 365,8 \mathrm{~cm})$ (ver figura 9). "El Lamento de las Imágenes" tangencia as questões que nos interessam aqui, uma vez que faz uma reflexão sobre as imagens, a cegueira coletiva em que vivemos, ou sobre os modos de nos dessensibilizar diante de certas imagens, o que podemos e o que não podemos ver/mostrar, quem detém este poder, a ideia do registro fotográfico como memória e testemunho, os processos de visibilização e invisibilização de certas imagens, além da própria ideia de arquivo como acervo destas imagens.

No primeiro painel o texto descreve a liberação de Nelson Mandela em 1990, depois de quase perder a visão em seu trabalho forçado nas minas de pedra calcária durante o cumprimento de parte dos 28 anos que foi condenado à prisão, fruto do regime do Apartheid (1948-1994) na África do Sul. Ver e não ver, abrir e fechar os olhos enceguecido diante da luz. O contraste entre o branco da pedra calcária e a pele de Mandela, luz e escuridão, liberdade e prisão, os brancos e os "não brancos", também da imagem e da incapacidade de chorar. Nós também nos sentimos envolvidos por estes contrastes: há que aproximar-nos, apertarmos os olhos para vermos, para podermos ler os textos, curvar-nos diante dos painéis de Jaar, como em um gesto de respeito ou reverência ante aqueles textos/imagens. Neste sentido, "quando lemos o texto, as palavras que nos iluminam também nos seduzem" (ACCATINO, 2006, p. 209)22.

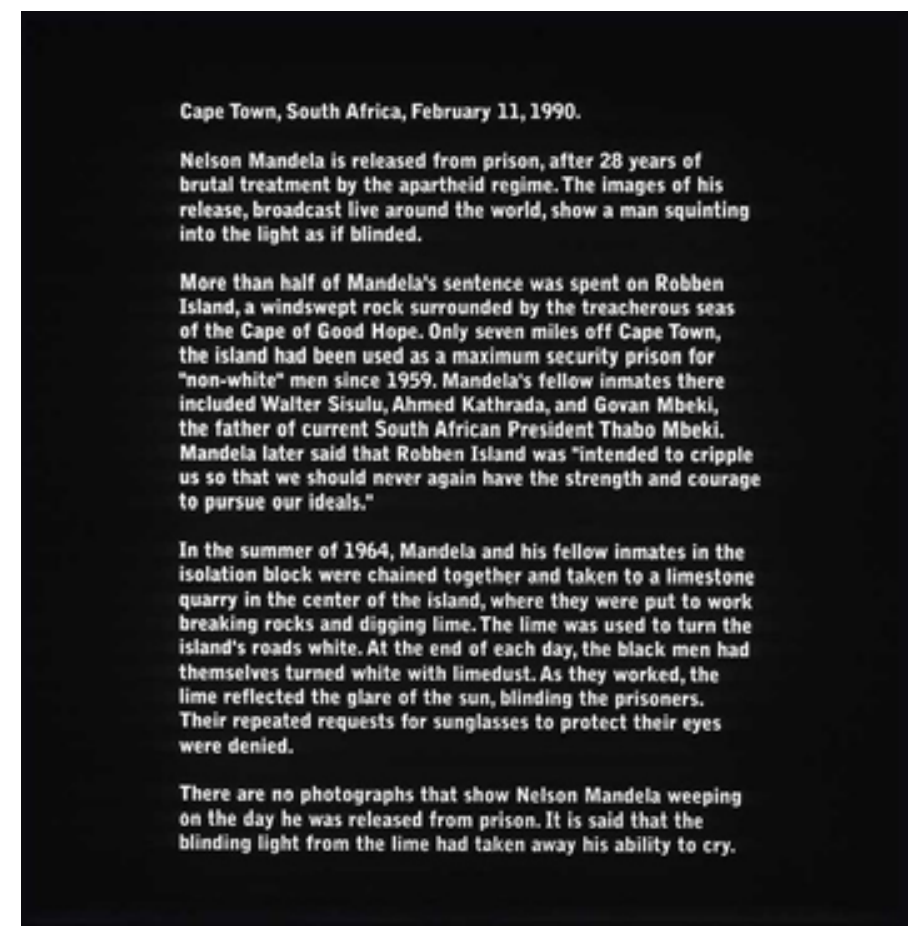

Fig. 6 - Alfredo Jaar: El lamento de las imágenes, 2002.

Fonte da imagem: Catálogo Alfredo Jaar: The Sound of Silence. Paris: kammel menour, 2012. S/p.

O segundo painel trata de outra mina, desta vez nos Estados Unidos, onde cerca de 17 milhões de fotografias foram enterradas em um antigo abrigo antiaéreo. 0 controle deste arquivo pertence a Bill Gates, provocando novos paradoxos diante deste imenso arquivo: subtrair, esconder, "proteger", conservar e mostrar tais ima-

22 Cuando leemos el texto, las palabras que nos iluminan también nos encandilan (tradução das autoras). 
gens, muitas delas de momentos históricos importantes, como os únicos registros de Nelson Mandela na prisão, e da chegada do homem na Lua. Com isso, Bill Gates comprou os direitos de circulação de milhões de imagens e as têm sequestradas no fundo de uma mina americana, a Iron Mountain National Underground Storage (Pennsylvania Ocidental). Sempre podemos contar com a venda dos registros digitais, apesar de que o trabalho de digitalização do acervo poderá levar mais de 400 anos (!). Trata-se do poder das imagens, o poder que uma única pessoa possui em mostrar e enterrar um acervo de quase 100 milhões de imagens.

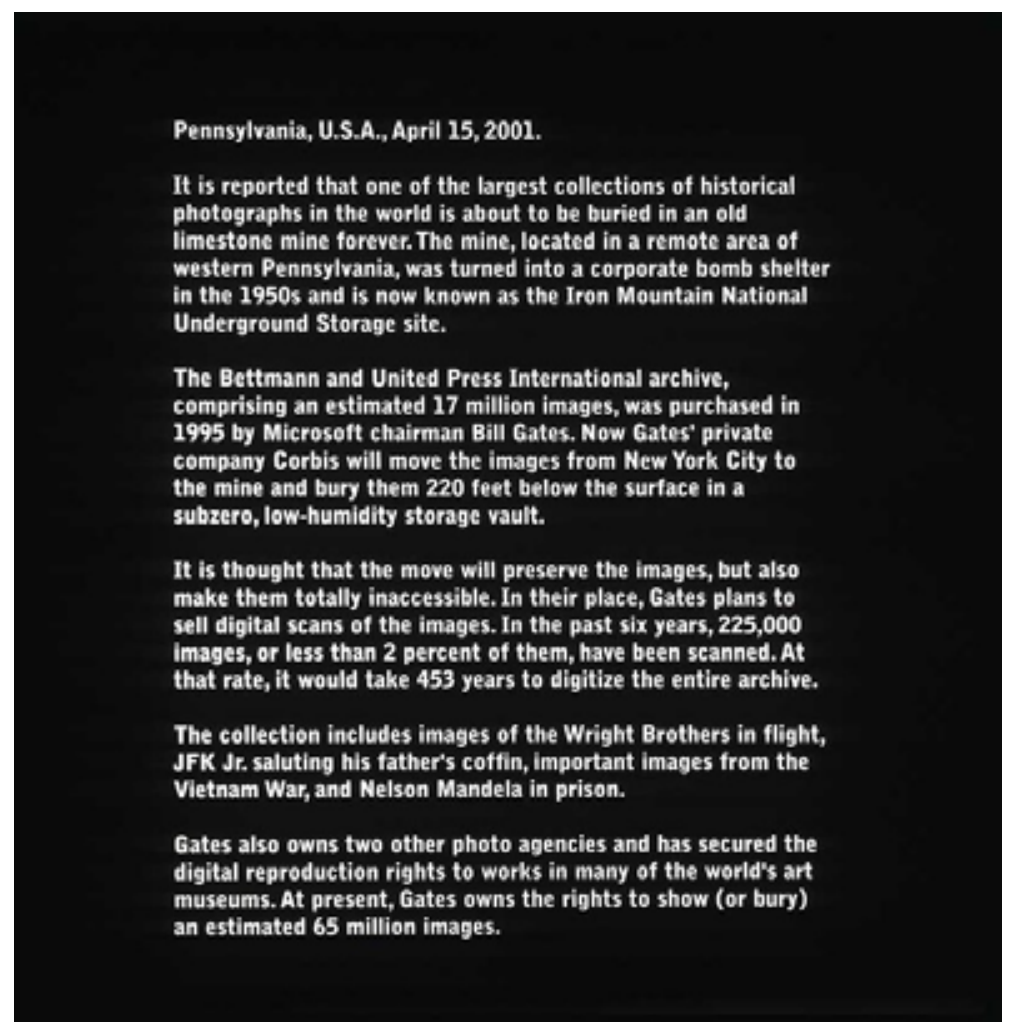

Fig. 7 - Alfredo Jaar: El lamento de las imágenes, 2002.

Fonte da imagem: Catálogo Alfredo Jaar: The Sound of Silence. Paris: kammel menour, 2012. S/p.

No último painel o texto nos informa sobre a estratégia adotada pelo Departamento de Defesa Norte-americano, antes mesmo de invadir o Afeganistão, ao comprar os direitos exclusivos de todas as imagens capturadas por satélites na região atacada. Proteger-se de possíveis ações indevidas do exército, como a morte de civis inocentes, antes mesmo de iniciado o conflito. Outra vez trata-se do poder das imagens, de seu controle e de sua circulação, de mostrar e apagar imagens/acontecimentos/vestígios. O que nos resta? O nada. E assim, seguindo pelo corredor escuro, chegamos ao final, a uma sala onde uma tela muito iluminada nos cegava com sua luz totalmente branca. É curioso observar algumas fotos do público observando a tela. Algumas franzem as sobrancelhas bem próximas à tela, para tentar ver algo, na esperança de que algo apareça, de que alguma imagem, ou palavra talvez, se materialize diante deles. Outros esboçam um leve sorriso como se fossem cúmplices do artista: entendi, não há nada que ver. 


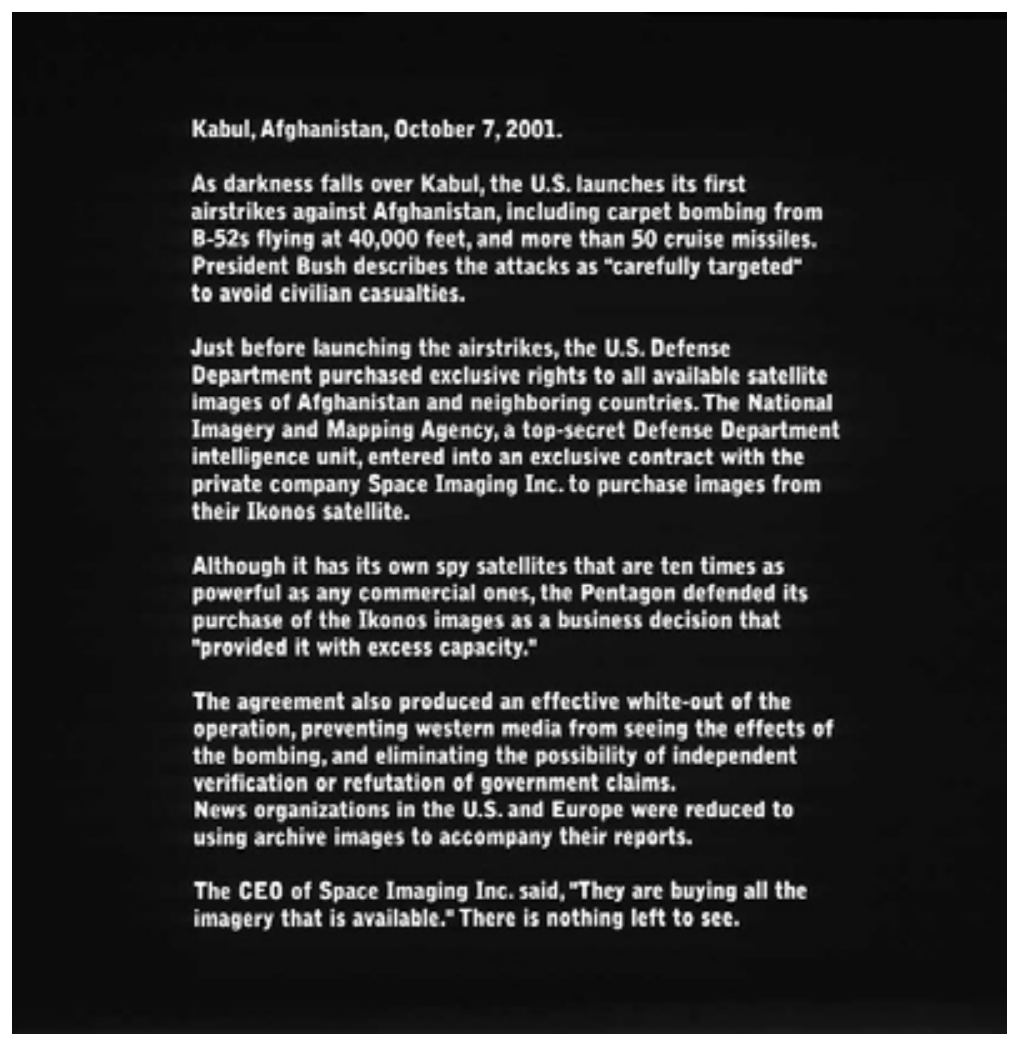

Fig. 8 - Alfredo Jaar: El lamento de las imágenes, 2002.

Fonte da imagem: Catálogo Alfredo Jaar. The Sound of Silence. Paris: kammel menour, 2012. S/p.

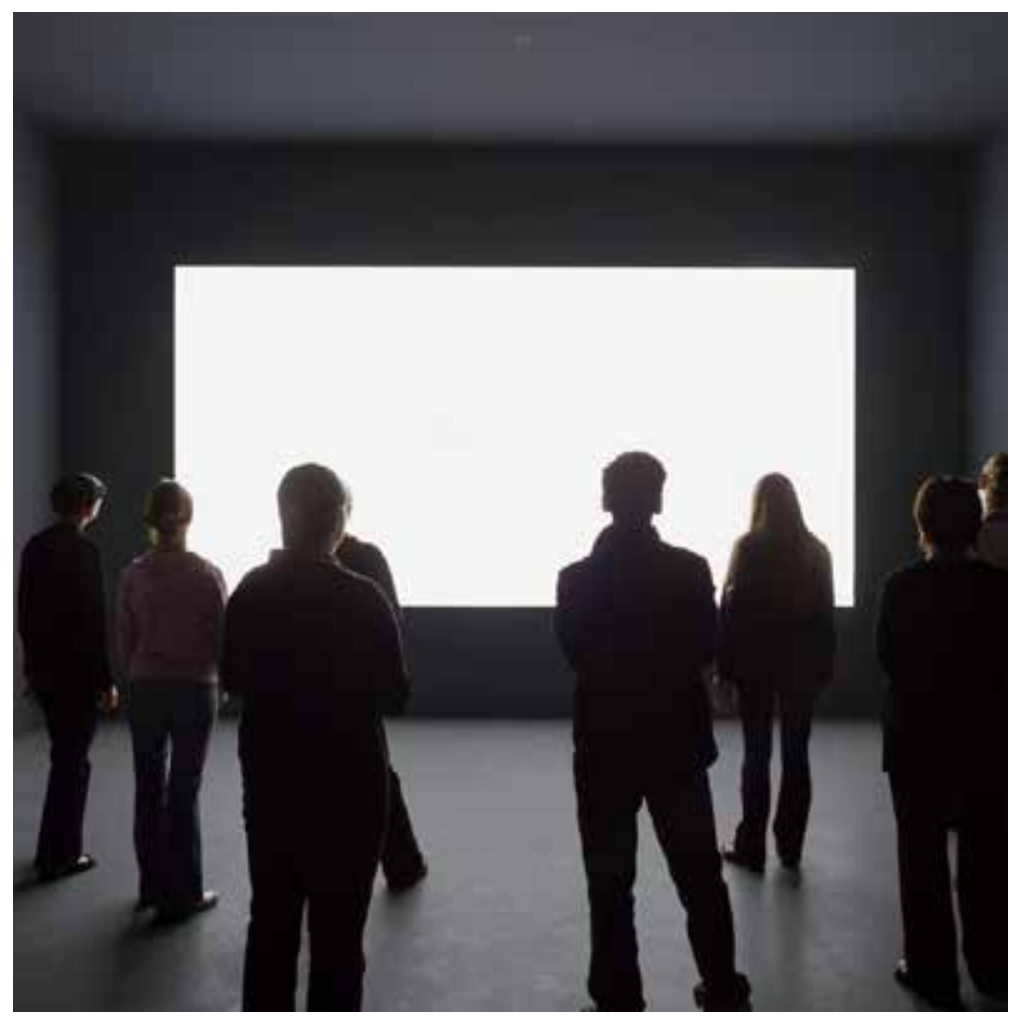

Fig. 9 - Alfredo Jaar: El lamento de las imágenes, 2002. Acervo MoMA, NY.

Fonte da imagem: Catálogo Alfredo Jaar. The Sound of Silence. Paris: kammel menour, 2012. S/p. 
Que poder terão estas imagens para que se invista tanto dinheiro e tantos esforços em controlá-las. Para Alfredo Jaar,

Isso é um paradoxo extraordinário, porque ao mesmo tempo que existe um bombardeio visual que nos aniquila a sensibilidade e nos anestesia, ao mesmo tempo nunca houve tanto controle das imagens. Estamos falando de um controle tanto a nível de corporações, de multinacionais ou de governos. Então eu acredito que o destino da humanidade está brincando com a imagem. Porque a falta de reação a imagens é um signo de nossa perda de humanidade. Quer dizer, se pensamos bem, se vamos à essência, de nossa palavra arquitetônica, se vamos à essência das coisas, como é possível que um ser humano não reaja diante de certas imagens? E tu não sais às ruas a protestar, tu não escreves a teus governos, tu não exiges dos governos a segurança, que hajam para parar tal massacre ou tal terror. Por quê? Aqui há duas possibilidades: ou estas imagens são signos, sintomas de uma sociedade que se tornou indiferente, ou são estas imagens que perderam a capacidade de afetar-nos e por tanto, de reagirmos" (JAAR, 2006) ${ }^{23}$.

Trata-se de uma obra emblemática, ao mesmo tempo em que estamos trespassados por uma avalanche de imagens, também o estamos pelo excesso e pelo vazio. Quer dizer, tudo o que vemos são as imagens que vemos? A chamada "realidade" corresponde exclusivamente às imagens que temos acesso? Não existe nada fora delas mesmas? E quanto aos milhares de imagens não vistas, que não circulam, ou dos fatos mesmos que não produzem registros fotográficos, não existiriam então? Vivemos entre um excesso de imagens visualizadas e uma falta de visibilidade de certos acontecimentos. Nos faz falta ver, conhecer, saber onde circulam (ou se escondem) imagens-chaves de nosso tempo.

\section{Em diálogo com Rosângela Rennó}

Em outro diálogo com a obra "La dernière bibliothèque", de Hubert Duprat, e suas novas formas de dar corpo à arte, de expor suas obras, de problematizar o que é mostrado e o que é somente sugerido, apresentamos Rosângela Rennó (1962-), artista cuja poética vem igualmente abordando o conceito de arte enquanto arquivo. Escolhemos um trabalho de Rennó onde podemos observar a subversão da biblioteca como espaço de conhecimento e pesquisa, sua obra nomeada "Bibliotheca" (2002). Percebemos neste trabalho também uma conexão com Alfedo Jaar, como veremos ao longo do texto. A obra se trata de uma instalação composta de 37 mesas de metal, cujas dimensões variam entre $80 \times 114.5 \times 81.5 \mathrm{~cm}, 80 \times 93 \times 43 \mathrm{~cm}$ et $80 \times 79.5 \times 70.5$ $\mathrm{cm}$; mapas-múndi de $40 \times 60 \times 4 \mathrm{~cm}$, um arquivo de metal e um livro. Esta instalação esteve exposta no Museu de Arte da Pampulha, em Belo Horizonte, e na galeria Fortes Villaça, em São Paulo, Brasil.

As mesas são compostas como vitrines, nas quais a artista colocou álbuns de fotografias de suas próprias coleções de imagens, datando do fim do século XIX che-

23 Eso es una paradoja extraordinaria porque al mismo tiempo que existe este bombardeo visual que nos aniquila la sensibilidad y nos anestesia, al mismo tiempo nunca ha habido tanto control de las imágenes. Estamos hablando de un control tanto a nivel de corporaciones, de multinacionales o de gobiernos. Entonces yo creo que el destino de la humanidad se está jugando la imagen. Porque la falta de reacción a las imágenes es un signo de nuestra pérdida de humanidad. Es decir, si uno lo piensa bien, si uno va a la esencia, de nuestra palabra arquitectónica, si uno va a la esencia de las cosas, ¿cómo es posible que un ser humano no reaccione ante ciertas imágenes? Y tú no sales a la calle a protestar tú no les escribes a sus gobiernos, tú no exiges a los gobiernos la seguridad que actúen para parar tal o tal masacre o tal horror. ¿Por qué? Aquí hay dos posibilidades: o esta imágenes son signos, síntomas de una sociedad que se ha vuelto indiferente o son estas imágenes que han perdido la capacidad de afectarnos y por lo tanto de reaccionar (tradução das autoras). 
gando aos anos de 1980. As vitrines são fechadas, o que torna os álbuns inacessíveis aos visitantes. A artista começou esta coleção há alguns anos, quando comprou um conjunto de fotografias em um mercado de pulgas em Bruxelas. Ao longo do tempo, foi aumentando sua coleção, procurando por fotografias em outros mercados de pulga em diversos lugares ao redor do mundo, e também recebendo de amigos e conhecidos que sabiam de sua prática e resolveram contribuir. Aqui vemos um diálogo com a coleção de Duprat, que começa e se desenvolve nos mesmos termos, ambos os artistas fazem disto uma prática cotidiana, mais do que um projeto que tem início, meio e fim, ambos fazem disto um hábito, uma paixão, que vai desencadear propostas além do arquivo, obras de arte. Após ter conseguido reunir uma grande quantidade de álbuns, Rennó escolhe alguns destes e, em um gesto radical, os enclausura dentro das mesas/vitrines.

A estrutura destas mesas foi feita em metal, cada mesa pintada de cor diferente; a parte superior das mesmas foi feita em acrílico, onde a artista imprimiu fotos, de maneira que os álbuns não pudessem ser vistos sob estas. As pessoas os viam somente olhando de lado. Os álbuns foram numerados de 1 a 100, sendo que em um arquivo de metal estavam os de 1 a 50, e no segundo os de 51 a 100. Rennó criou um sistema de indicação desde a origem até o destino das imagens: os álbuns foram classificados em 10 grupos indicando as referências associadas às etiquetas fixadas na parede, segundo a cor da mesa e a cor dos pinos fixados nos mapas. O código definia uma cor por continente: a cor do fundo correspondendo ao local onde a foto havia sido tirada, a cor da estrutura da mesa correspondendo ao local onde foi adquirida. Haviam grupos de Cuba, Estados Unidos, França e Alemanha, entre outros lugares. Os mapas foram fixados nas paredes a fim de situar geograficamente as fotos.

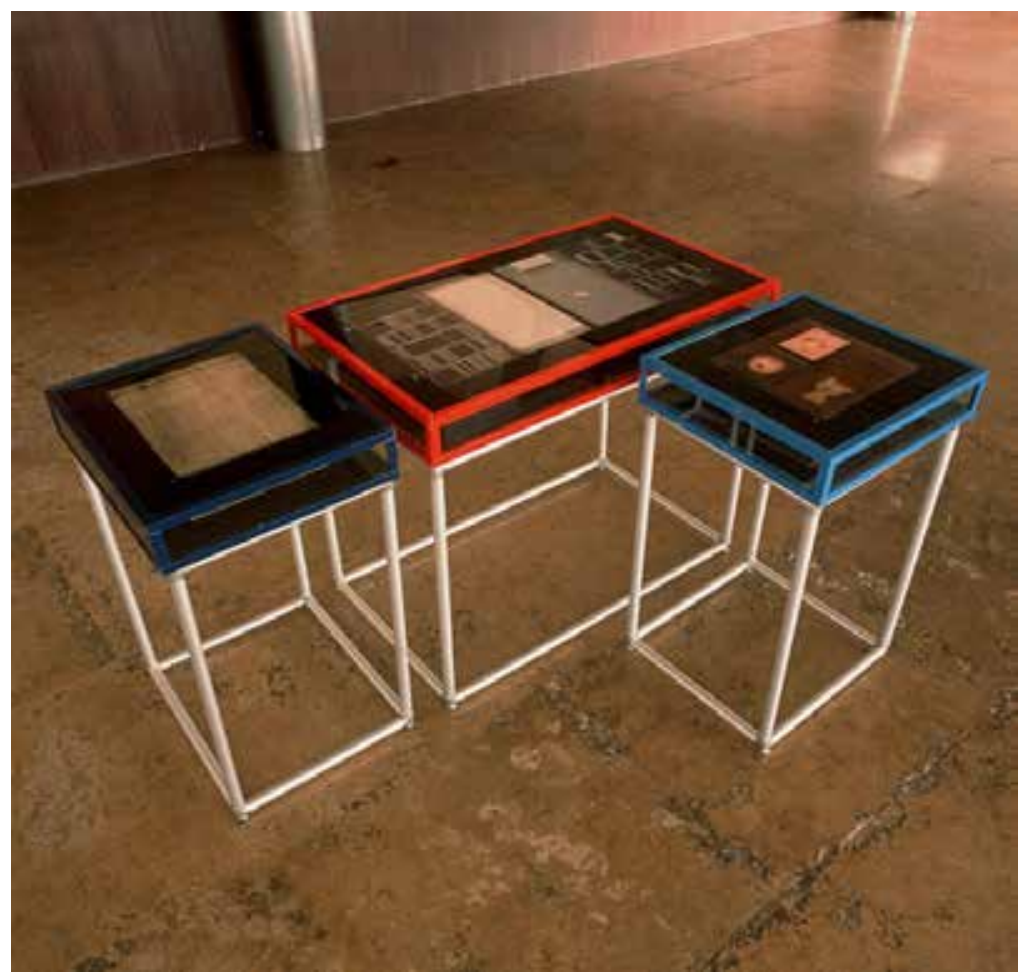

Fig. 10 - Rosângela Rennó.Bibliotheca, 2002, vista geral da instalação.

37 vitrines contendo álbuns de fotos antigas, fotos coloridas impressas em acrílico, cartão e arquivo de metal.

Fonte da imagem: http://www.rosangelarenno.com.br/obras/exibir/13/12 
No arquivo estavam as fichas catalográficas dos 100 álbuns, contendo informações como o formato do álbum, as características da capa (rígida, costurada, etc.), a cor e o tipo de papel, número de páginas, número de imagens, formato e conteúdo das fotografias, descrição textual das fotos e notas aferentes, tais como quando e onde as fotos foram tiradas e adquiridas, e até mesmo curiosidades sobre as imagens. Ao lado deste arquivo encontrávamos o livro, chamado também de "Bibliotheca", que não continha texto algum, somente imagens dos álbuns catalogados: uma imagem de cada álbum, as quais estavam identificadas também nas fichas do arquivo, lembrando que os álbuns estavam inacessíveis, fechados nas vitrines. O título, "Bibliotheca" (do livro e da obra), se referia ao mesmo tempo a alguma coisa de antigo, que vale a pena ser guardado (arquivo, memória, coleção), e ao famoso livro de Bizâncio do século IX, também chamado de "Bibliotheca"24. Encontramos alguns métodos próximos aos de Duprat: a organização arquivista, a relação com a história, o impulso da coleção, mas também a referência à erudição e a algo mais que o que está sendo mostrado, algo que vai além da própria obra e requer do visitante sua participação. Rennó referencia o famoso livro, trazendo um pouco de história cultural enviesada, pois só o espectador que conhece esta história pode reconhecer a ligação. Duprat traz Warburg da mesma maneira, por movimento, e não por legenda, então só aquele que conhece o historiador, sua história e seu Atlas, consegue entender de onde vêm os painéis. Mas não tem sido assim ao longo da história da arte? Não eram assim também desde as pinturas rupestres, imagens-enigma a serem decifradas pelo sujeito, cada qual armado com seu próprio arsenal? Ao dar acesso às informações, como em Duprat, ao negar acesso a elas, como em Rennó, os artistas estão trazendo questões milenares da arte, onde é o espectador que completa a imagem, e dá sentido à obra. Onde estes artistas nos provocam? Quando transformam suas obras em outra coisa, de outra forma: álbuns inacessíveis, sites que contam tudo.

Ao bloquear o acesso visual às informações privadas contidas em cada álbum, a artista rompe claramente com a relação estreita que existe entre a fotografia, e o local e momento onde foi tirada, o que as faz pertencer a um espaço indistinto e sem memória. Rennó esconde as imagens para que apenas a sua evocação indicial as disponibilize e possam ser reinventadas, a partir de várias referências nas mentes daqueles que não conseguem vê-las nos álbuns. Aqui temos o confronto entre texto e fotografia como meio de aproximação de um fato. Mesmo a consulta mais atenta desses registros não corresponde à experiência de olhar as próprias fotos.

Quanto ao tamanho e montagem da instalação, que consiste em expositores grandes e coloridos, contendo uma ampla gama de álbuns de fotos e outras formas de armazenamento da imagem fotográfica - suntuosos álbuns cobertos de veludo do século XIX, álbuns plásticos descartáveis, próprios do contemporâneo - podemos dizer que o pequeno arquivo catalográfico e o livro de imagens na parede, na parte inferior do espaço de exposição, ocupam uma posição tímida.

Assim podemos trazer algumas reflexões sobre a relação entre o álbum da família e a memória, bem como entre a imagem fotográfica, a narração e a imagi-

24 Foi uma obra de Photius, um bizantino do século IX, dedicada a seu irmão e composta por 279 revisões de livros que ele havia lido. 0 livro não deveria ser usado como trabalho de referência, mas era amplamente utilizado como tal no século IX, e geralmente é considerado o primeiro trabalho bizantino que poderia ser chamado de enciclopédia. Os textos que ele incorporou neste livro são, na sua maioria, de autores cristãos e pagãos do século $\mathrm{V}$, e de seu tempo, o século IX. Quase metade dos livros mencionados não sobreviveram. 
nação. Philippe Artières, no texto "Arquivar a própria vida", publicado no Brasil em 1998, analisa um costume compartilhado por nós, o arquivamento da vida. Nós estaríamos constantemente selecionando e registrando fatos e coisas, de um simples bilhete de metrô a imagens fotográficas pessoais, de modo que os vestígios de nossa existência estariam sempre em alguns tipos de arquivo. No entanto, esses arquivos só podem ser dados em fragmentos, preservaremos apenas uma pequena parte de todos esses vestígios; após a perda e o apagamento da memória, esses vestígios, esses fragmentos de uma totalidade perdida, seriam o que reconstruirão as imagens perdidas. A coleção desses fragmentos seria uma maneira de salvar, mesmo que não tudo, pelo menos parte da nossa vida, muito preciosa para se perder ao longo do tempo corrosivo. A busca para salvar esses objetos representaria a busca para nos salvar, para construir significados para a própria existência, a partir desta coleção de memórias selecionadas.

Paradoxalmente, Rosângela Rennó deslocou essa coleção do privado e a tornou pública ao incluí-la em uma obra de arte, mas a artista tornou o conteúdo desses álbuns inacessíveis, o que questiona o conceito de público. Rennó bloqueou o interior dos álbuns, que o visitante dificilmente pode ver pelo aspecto exterior de suas capas, já que a parte superior das vitrines não é vidro transparente.

Em Rosângela Rennó e sua "Bibliotheca", os documentos são mostrados, mas escondidos ao mesmo tempo. A artista seleciona uma grande quantidade de documentos, mas só oferece uma pequena porção. Em Duprat o movimento é o oposto, o artista seleciona o máximo possível de documentos relacionados ao assunto da exposição, os disponibiliza todos, e ainda os coloca online, para que os interessados que não tiveram acesso à exposição, ainda tenham a chance de obter a informação, seja ela científica ou literária.

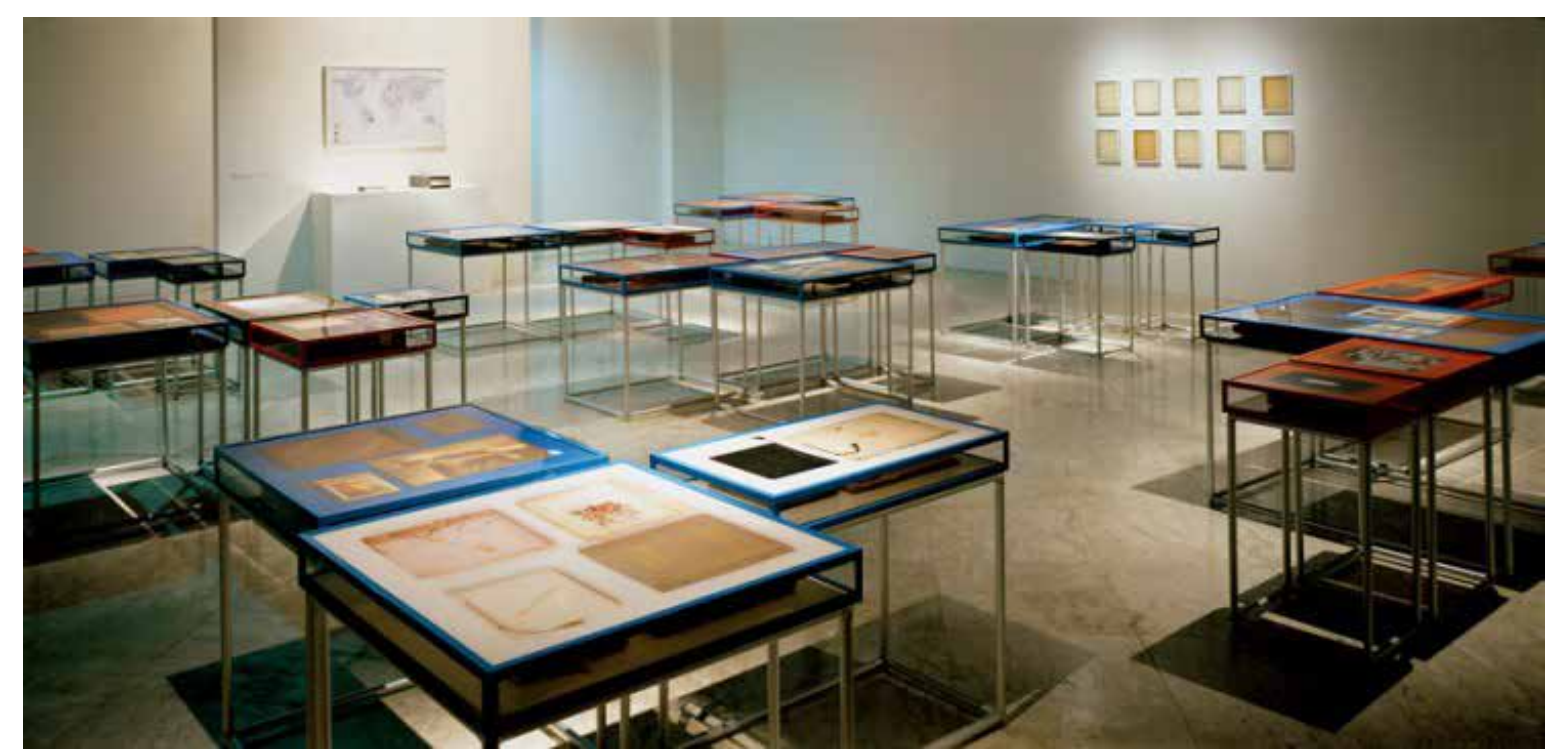

Fig. 11 - Rosângela Rennó. Bibliotheca, 2002, vista geral da instalação.

37 vitrines contendo álbuns de fotos antigas, fotos coloridas impressas em acrílico, cartão e arquivo de metal. Fonte da imagem: http://www.rosangelarenno.com.br/obras/view/13/1 
Percebemos nos três artistas abordados questões que os conectam: a atenção ao livro como objeto, como ícone, como fonte de conhecimento, como material artístico. O movimento arquivista, e o procedimento de convidar o espectador a descobrir mais por si mesmo, não dando facilmente a chave da sua obra. A montagem da exposição prefigurando espaços de saber: a sala de aula, a biblioteca, o espaço de pesquisa. A reinvenção das formas de expor, das formas de criar a obra. Os três artistas transitam pelas fronteiras da arte enquanto estratégia de não esquecimento, de forjar um espaço de memória além daqueles que nos são previamente dados.

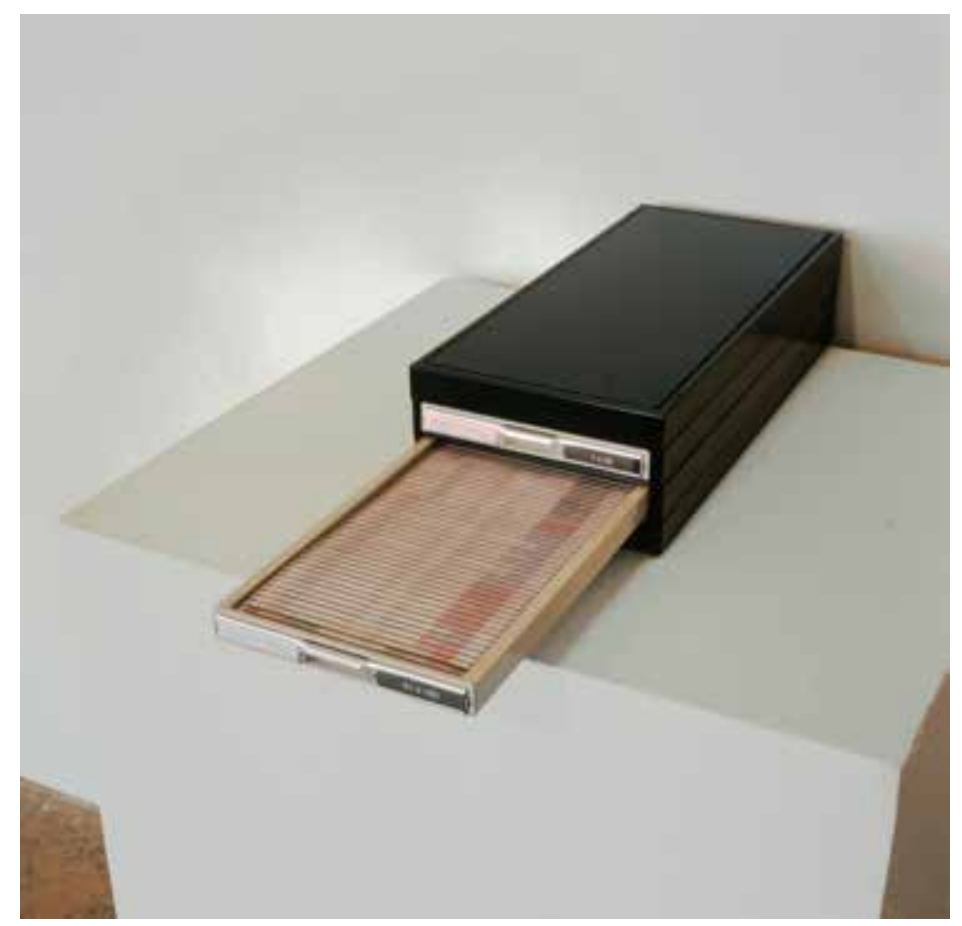

Fig. 12 - Rosângela Rennó

Bibliotheca, 2002, arquivo em metal.

Fonte da imagem: http://www.rosangelarenno.com.br/obras/view/13/3

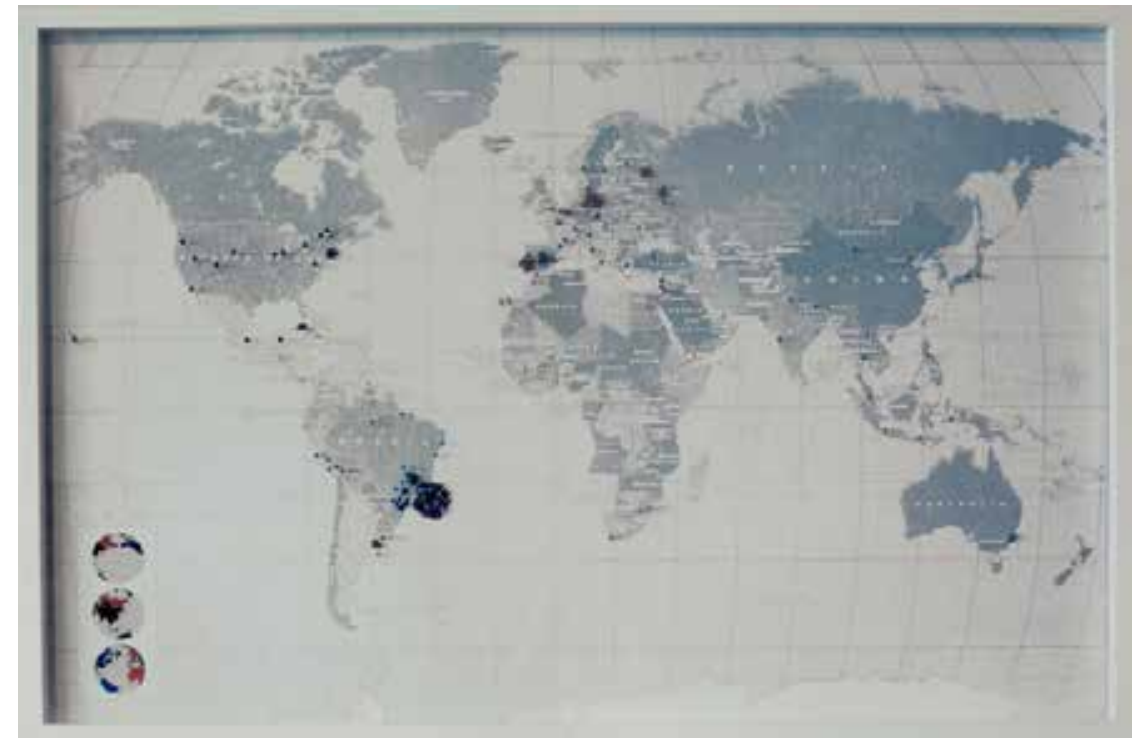

Fig. 13 - Rosângela Rennó.

Bibliotheca, 2002, mapas.

Fonte da imagem: http://www.rosangelarenno.com.br/obras/view/13/3 
Rosângela Rennó remove a fotografia como foco principal do trabalho e bloqueia o acesso direto às imagens em seu contexto original, questionando o conceito de fotografia "real", já que aos espectadores ela dá apenas descrições das imagens, supostamente verdadeiras. A tradição de dar objetividade à imagem fotográfica é subvertida quando a artista nos impede de verificar se as descrições são "reais".

De acordo com a artista, "Bibliotheca" não é sobre imagens. "Bibliotheca" é sobre os álbuns. $O$ ato de colecionar. Desta forma, Rennó nos conta seu interesse: o arquivo. A artista construiu um trabalho que conecta o formato e o conceito de arquivo como um local de salvação, de organização da memória. Mas faz isso de uma maneira crítica, já que, através da sua instalação, Rennó nos propõe refletir se essas memórias/imagens correspondem à realidade e se nossas memórias também correspondem ao nosso passado. A artista questiona o poder do arquivo como documentação verdadeira. Nos oferece uma reflexão sobre a forma pela qual acessamos informações e memórias em nossa sociedade, especialmente quando nos referimos à internet, o arquivo mais democrático e o mais fácil de acessar. E depois chegamos ao arquivo de Duprat, o site na Internet com toda a documentação sobre as larvas Tricópteras, documentação científica, ficcional, lendária, mitológica. Um site que se tornou espaço de pesquisa.

$\mathrm{Na}$ "Bibliotheca" Rennó nos traz as fotos da família: a fotografia doméstica ajuda na construção de uma memória familiar. Os álbuns de família ajudam a construir uma identidade coletiva e individual através da referência criada por imagens e pela história oral que os acompanha (LANGFORD, 2001). Mas quando esses álbuns deixam o domínio privado, seu ambiente familiar, seu ambiente histórico, o que temos é uma coleção de fotografias que pode ser interpretada de diferentes maneiras, dependendo do tempo e do lugar, assumindo um modelo de período determinado.

No contexto da cultura da memória, essas fotografias podem se tornar materiais em coleções iconográficas de museus, seu objetivo é salvar os costumes e a memória visual de uma época, lugar ou cultura, de onde vieram. Outra possibilidade é que essas fotografias se tornem materiais de mercado de pulgas, curiosidades, vendidas como relíquias ou colecionáveis. Rosângela Rennó é uma colecionadora, ampliou sua coleção de fotografias ao longo dos anos e as usou em várias instalações artísticas. "Bibliotheca" é apenas um desses exemplos.

De acordo com Maria Angélica Melendí (2003), a artista se apropria das memórias dos outros e as evoca, como espelhos, para que possamos nos ver nessas imagens. Alfredo Jaar coleciona memórias de saberes, livros e reflexões conhecidas, as reúne num mesmo tempo e lugar, convidando o público para que as descubra e reorganize. Duprat nos oferece a sua própria unidade de arquivo, seu próprio desejo de colecionar, é uma questão de salvar a memória que para o artista se torna obra, se torna arte.

\section{Referências}

ACCATINO, Sandra (2006). Estrategias de visibilidad. In: VALDÉS, Adriana (Ed.) Catálogo de la exposición JAAR SCL 2006. Barcelona: Actar. 
ARTIÈRES, Philippe. Arquivar a própria vida. In: Estudos históricos. 1998, vol. 11, n. 21, pp. 9-34.

BESSON, Christian. "La Bibliothèque du Trichoptère ». [Communication au colloque Le Temps exposé. 2, Nîmes, École supérieure des beaux-arts, 9-10 avril 2013. Publié in Temps exposé. Histoire et mémoire dans l'art récent, sous la dir. de Natacha Pugnet, Nîmes, École supérieure des beaux-arts, 2015.] Disponível em: http://www.besson.biz/ bibliotheque-trichoptere/ com acesso em 20 de agosto de 2015.

DERRIDA, Jacques. Mal de Archivo. Uma impresión freudiana. Madrid: Trotta, 1997.

ENWENSOR, O. Alfredo Jaar's Art of Ilumination. In: Alfredo Jaar. The Sound of Silence. Kamel Mennour, Paris, 2012.

GUASCH, Anna Maria. Os lugares da memória: a arte de arquivar e recordar. IN: Revista-Valise, Porto Alegre, v. 3, n. 5, ano 3, julho de 2013.

KLINGER, Diana (UERJ). Paixão do arquivo. IN: MATRAGA 21 - Estudos linguísticos e literários - revista do programa de pós-graduação em letras. 2008. S/p. Disponível em: http://www.pgletras.uerj.br/matraga/matraga21/PAIXAO\%20DO\%20ARQUIVO.html Com acesso em 15 de agosto de 2015.

JAAR, Alfredo, entrevista a Cristián Warnken (2006).

Disponível em: http://www.unabellezanueva.org/alfredo-jaar/

LANGFORD, Martha. Suspended conversations: the afterlife of memory in photographic albums. Montreal: McGill-Queen's University Press, 2001.

MELENDI, Maria Angélica. "Biblioteca ou das possíveis estratégias da memória". In: RENNÓ, Rosângela. O arquivo universal e outros arquivos. São Paulo: Cosac\& Naify, 2003.

MONEGAL, Antonio. "Alfredo Jaar y el archivo de las Imágenes omitidas" ponencia presentada en el Seminari Internacional Politques d'arxiu: la noció d'arxiu i les pràctiques artístiques conteporànies. Universitat de Girona, Girona, 19, 20, 21 de diciembre de 2011. Disponível em: diobma.udg.edu/handle/10256.1/2326

RENNÓ, Rosângela. 2011, s/p. In: ALBERTONI, Fernanda. Do domínio da informação a memórias materiais: estratégias do arquivo na obra Bibliotheca de Rosângela Rennó. Revista-Valise, Porto Alegre, v. 5, n. 10, ano 5, dezembro de 2015.

http://www.smba.nl/en/exhibitions/the-marx-lounge/

http://www.smba.nl/static/en/exhibitions/the-marx-lounge/smba-newsletter-121. pdf 